\title{
Treatment of Dystrophic Epidermolysis Bullosa with Transforming Powder Dressing
}

\author{
Steven P Smith MD* \\ Consultant, Dermatology and Mohs Surgery, Uluru Inc, USA \\ Submission: July 21, 2020; Published: July 30, 2020 \\ *Corresponding author: Steven P Smith MD, Consultant, Dermatology and Mohs Surgery, Uluru Inc, USA
}

Abstract

Dystrophic epidermolysis bullosa is a disabling blistering disorder, characterized by significant pain, extensive nursing care, and difficult wound healing. The following case presents a transforming powder dressing which provided pain reduction, atraumatic and reduced dressing changes, as well as improved healing in one patient.

Keywords: Dystrophic Epidermolysis Bullosa; Wound Healing; Skin Fragility; Chronic Erosions, Scarring; Squamous Cell Carcinoma

\section{Case Report}

An 18-year-old white male with dystrophic epidermolysis bullosa predominantly involving both knees, back, buttocks and thighs had undergone long-term wound care with products including a silicone foam (Mepilex, Molnlycke Health Care, Gothenburg, Sweden) and a polymeric membrane dressing (Polymem, Ferris Manufacturing Corp., Fort Worth, TX, USA). Daily dressing changes averaging 1.5 hours in length were performed by wound care nurses, as well as a full bath with antimicrobials twice weekly. In hopes of reducing the length of daily dressing changes, as well as the significant wound pain and pruritus, a new treatment was introduced in February 2015. Transforming powder (Altrazeal, Uluru, Inc., Addison, TX, USA) was applied following the twice-weekly antimicrobial baths, initially to small wounds on the knees (in order to evaluate both patient comfort and product efficacy). By early summer 2015, both knees were completely healed. Re-epithelialization was rapid, with decreased pain and pruritus. After an unrelated hospitalization in late summer 2015 allowed for a flare of the disease, transforming powder application began on the entire knees and the back in October 2015.

Complete dressing changes, which previously were performed on a daily basis and required 1.5 hours of time, were now reduced to twice weekly (following antimicrobial baths). Wounds were cleansed with an antimicrobial solution (Microdacyn, Sonoma Pharmaceuticals Netherlands, B.V., Roermond, The Netherlands) and transforming powder was applied. A perforated silicone contact layer (Mepitel, Molnlycke Health Care, Gothenburg, Sweden) and soft nonwoven swabs were employed as secondary dressings. With the use of transforming powder, dressing changes were now painless. Throughout the end of 2015 and early 2016 there was significant re-epithelialization of the knee and back wounds (Figures 1-4), along with major reduction of pain and pruritus.

\section{Discussion}

Epidermolysis bullosa is a group of genetic blistering disorders characterized by abnormal skin fragility. This fragility results in painfulvesicles and bullae, which maytransform to chronicerosions, scarring and squamous cell carcinoma. The involved skin is often painful and pruritic [1]. Dermatologic therapy for epidermolysis bullosa consists of supportive care aimed at improving discomfort, preventing infections, and promoting healing. Often such objectives require lengthy, frequent treatment episodes, which, although well-intended, only further add to the psychological and physical burden of the disease. Transforming powder is a polymer composed of primarily poly-2-hydroxyethylmethacrylate and poly-2-hydroxypropylmethacrylate. Contact with wound exudate in epidermolysis bullosa causes the polymer particles to irreversibly aggregate into a flexible gel dressing, contouring precisely to the wound. Essentially, the wound is now covered with a moist, custom dressing. The dressing has a high porosity, enabling the passage of oxygen to the wound [2]. However, the 
pores are too small to permit exogenous bacteria to penetrate, keeping a clean wound environment. Finally, a moist wound bed is maintained while excess moisture is drawn through the dressing by evaporation at the surface [3].

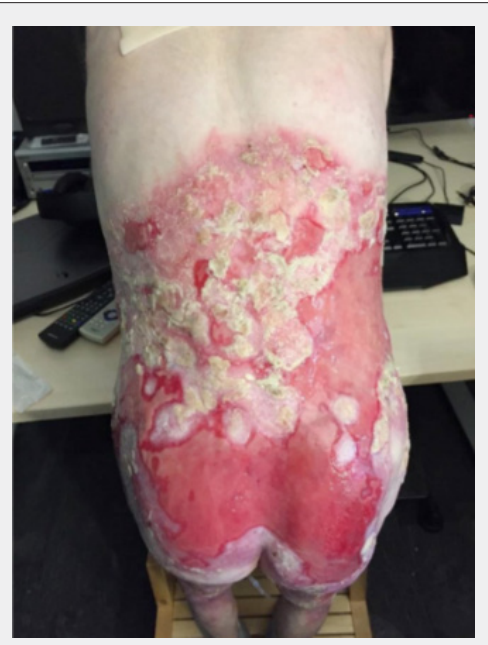

Figure 1: Back wound prior to treatment (24.10.2015).

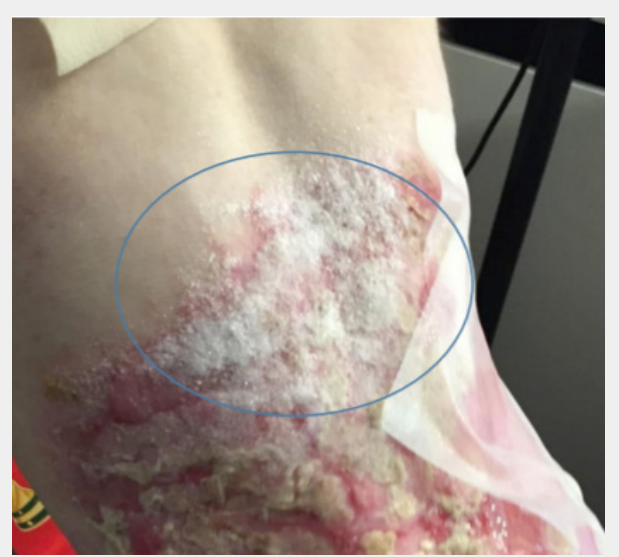

Figure 2: Application of transforming powder (24.10.2015).

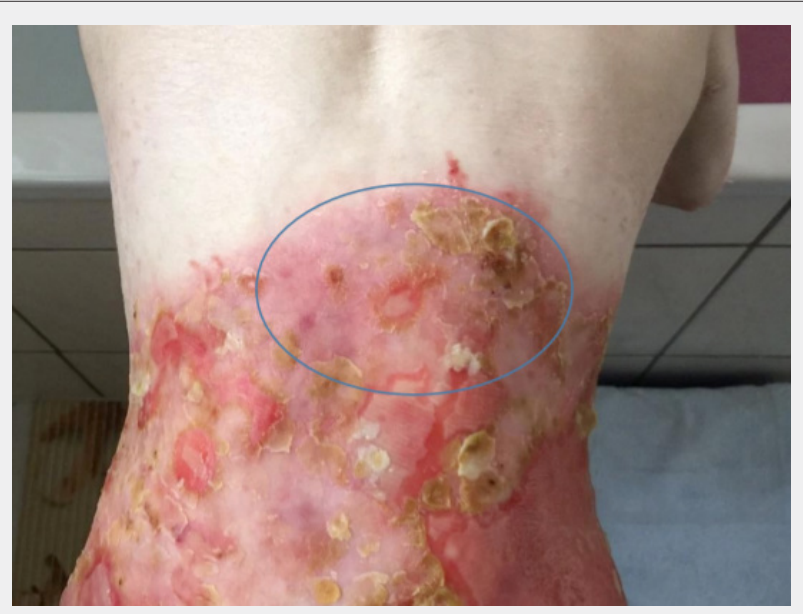

Figure 3: Marked healing after three weeks of treatment (14.11.2015). 


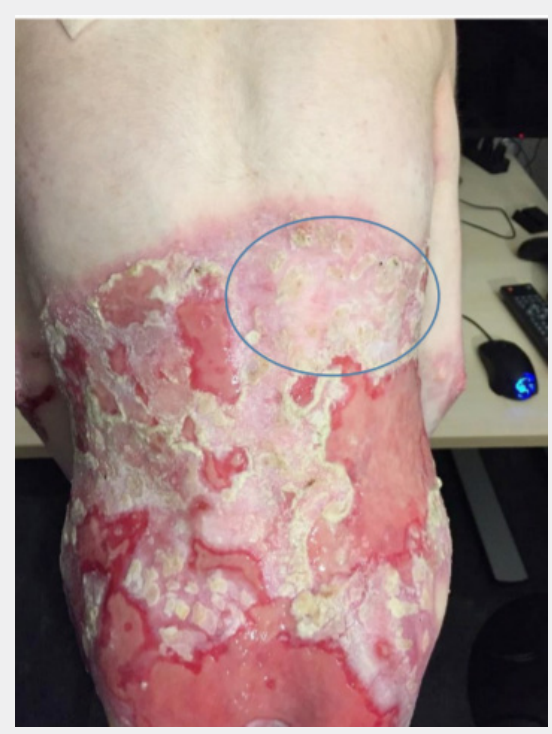

Figure 4: Complete re-epithelialization after seven weeks of treatment (12.12.2015).

The dressing can remain in place for up to 30 days. Eventually, healing of the wound results in the gel being transformed to a dry crust, which flakes off when healing is complete. Alternatively, the gel can be removed by saturating it with water, as was the case with baths performed on this patient. As newly formed wound tissue does not penetrate the dressing, removal does not disrupt or harm the healing wound. Removal is therefore entirely painless, an especially valuable attribute for epidermolysis bullosa patients. As mentioned above, the application of transforming powder significantly decreased wound pain for this patient. This has also been noted with venous leg ulcers, pyoderma gangrenosum, sickle cell ulceration, and split thickness skin graft donor sites [4-6]. Postulated pain reduction mechanisms include reduced inflammation, high moisture vapor transmission rate, substance P blockade, and binding of bacterial toxins [2,5]. With this patient, transforming powder dressing was covered with an absorbent secondary dressing, in order to control the significant wound exudate. A contact layer was placed between the two dressings to avoid gel adherence to the secondary dressing. This technique allowed complete dressing changes to be reduced from daily to twice weekly. Only the secondary dressing needed to be changed on the other days. This resulted in significantly less nursing time, and, more importantly, less lost time for the patient.

\section{Conclusion}

The use of transforming powder enabled improved healing, decreased pain and pruritus, and significantly reduced dressing care time in a patient with dystrophic epidermolysis bullosa. The powder transforms into a gel dressing that contours precisely to the wound, while not penetrating it. The porosity of the gel dressing allows oxygenation of the wound and water vapor transpiration, while excluding exogenous bacteria. Transforming powder is a new wound treatment option for a very difficult and debilitating disease.

\section{References}

1. Marinkovich MP, Herron GS, Khavari PA, Bauer EA (1999) Hereditary Epidermolysis Bullosa. In: Freedberg IM, Eisen AZ, Wolff K, Austen KF, Goldsmith LA (eds.) Dermatology In General Medicine, $5^{\text {th }}$ edn, New York, USA.

2. Fitzgerald RH, Bharara M, Mills JL, Armstrong DG (2009) Use of a Nanoflex powder dressing for wound management following debridement for necrotizing fasciitis in the diabetic foot. International Wound Journal 6(2): 133-139.

3. Fraccalviri M, Morozzo U, Salomone M, Ruka E, Fava R (2014) A novel methacrylate powder dressing (Altrazeal) for hard-to-heal wounds: Case report. Acta Vulnologica 12(4): 187-192.

4. Assadian O, Arnoldo B, Purdue G, Burris A, Skrinjar E, et al. (2015) A prospective, randomized study of a novel transforming methacrylate dressing compared with a silver-containing sodium carboxymethylcellulose dressing on partial-thickness skin graft donor sites in burn patients. International Wound Journal 12(3): 351-356.

5. Milne CT, Serendipity SD (2010) Use of a novel transforming powder dressing to treat chronic wounds reduces lower extremity wound pain in patients with venous wounds. Paper presented at SAWC Meeting, Orlando, USA.

6. Vlahovic TC, Lee, DW, Oliver M (2009) Clinical observations on the use of a novel transforming powder dressing in the treatment of atypical wounds. Paper presented at the APWCA Meeting, Philadelphia PA, USA. 


\section{Your next submission with Juniper Publishers will reach you the below assets}

- Quality Editorial service

- Swift Peer Review

- Reprints availability

- E-prints Service

- Manuscript Podcast for convenient understanding

- Global attainment for your research

- Manuscript accessibility in different formats

( Pdf, E-pub, Full Text, Audio)

- Unceasing customer service

Track the below URL for one-step submission https://juniperpublishers.com/online-submission.php 